EMPOWER : Jurnal Pengembangan Masyarakat Islam

Vol. 4, No. 2, Desember 2019, hlm. 279-298

e-ISSN : 2580 - 0973, p-ISSN : 2580-085X

Tersedia Online di : http://syekhnurjati.ac.id/jurnal/index.php/empower

Email : empower@syekhnurjati.ac.id

\title{
Transformasi Sosial Komunitas Petani Kentang Di Dataran Tinggi Dieng
}

\author{
Turasih
}

IAIN Syekh Nurjati Cirebon

Email: turasih@gmail.com

\begin{abstract}
Abstrak
Komoditas kentang yang hadir setelah era jagung dan tembakau di Dataran Tinggi Dieng pada tahap awal berkontribusi secara signifikan terhadap aspek ekonomi petani. Harga jual tinggi dan musim tanam pendek menyebabkan petani melakukan aktivitas pertanian kentang secara intensif. Masuknya komoditas kentang menyebabkan modernisasi pertanian dan menciptakan kesenjangan stratifikasi sosial masyarakat petani dalam hal penguasaan moda produksi. Pertumbuhan penduduk kemudian memperumit persoalan tersebut. Aktivitas pertanian merambah pada perusakan lingkungan atas dasar kebutuhan pertanian dan pemukiman. Dampaknya adalah berkurangnya daya dukung lingkungan dan juga pendapatan petani. Sistem pertanian modern di dataran tinggi Dieng menciptakan struktur ekonomi baru yang berkaitan dengan pasar kapitalis dan berkontribusi pada kerusakan ekologi. Permasalahan yang terjadi di dataran tinggi Dieng menarik perhatian berbagai pihak untuk melakukan pemulihan melalui proses 'pemberdayaan'. Sayangnya, proses pemberdayaan yang dilakukan masih bias teknis dan menjadikan masyarakat miskin serta petani sebagai objek.
\end{abstract}

Kata kunci: transformasi pedesaan dataran tinggi, perubahan sosial, komuniyas pedesaan, modernisasi pertanian, pemberdayaan

\begin{abstract}
Potato commodities present after the era of corn and tobacco in Dieng Plateau in the early stages contribute significantly to the economic aspects of farmers. High selling price and short planting season cause farmers to do the potato farming activities intensively. The inclusion of potato commodities led to the modernization of agriculture and created the social stratification gap of farmer communities in terms of production mode mastery. Population growth then complicate the issue. Agricultural activities have penetrated the environmental destruction on the basis of agricultural and residential needs. The impact is reduced
\end{abstract}


environmental support and also the income of farmers. The modern agricultural system in Dieng Plateau creates a new economic structure relating to the capitalist market and contributes to ecological damage. The problems that occur in Dieng Plateau attract the attention of various parties to perform the recovery through the process of 'empowerment'. Unfortunately, the empowerment process is still technically biased and makes the poor as well as the farmer as an object.

Keywords: Highland rural transformation, social change, rural community, agricultural modernization, empowerment

\section{A. Pendahuluan}

Sebelum komoditi kentang masuk ke kawasan Dataran Tinggi Dieng, petani mengusahakan tanaman tembakau dan palawija di lahan pertaniannya. Seiring dengan kenyataan bahwa kentang memiliki nilai ekonomis lebih tinggi dibanding dengan tembakau dan palawija maka kemudian petani beralih mengusahakan tanaman kentang. Orientasi aktivitas pertanian pada era kentang adalah untuk mengejar keuntungan materi dan peningkatan produktifitas ${ }^{1}$. Berubahnya komoditi pertanian, terjadi juga perubahan sistem pertanian yang sekaligus mempengaruhi proses-proses sosial yang berlangsung di komunitas petani kentang di Dataran Tinggi Dieng.

Hal yang kemudian menjadi polemik adalah moda produksi pertanian utama yaitu lahan pertanian dikuasai oleh petani-petani kaya. Begitu pun akses terhadap teknologi (pupuk dan pestisida) lebih mudah dicapai oleh mereka karena memiliki pendapatan yang tinggi dari pertaniannya, sedangkan petani kecil berpendapatan rendah adalah kelompok paling akhir yang mampu responsif terhadap teknologi modern. Selain itu, tekanan kepentingan ekonomi menyebabkan terjadinya perambahan lahan kawasan lindung di dataran tinggi Dieng yang menjadi area tangkapan (catchment area) bagi daur hidrologi. Akhirn ya pertanian kentang berada di 'posisi antara' yakni di satu sisi dipertahankan petani sebagai mata pencaharian utama dan di sisi lain

\footnotetext{
${ }^{1}$ Hal ini serupa dengan apa yang terjadi pada masa bimbingan massal (BIMAS) digalakkan (Sajogyo, 1982), dimana petani kemudian terdorong untuk menghasilkan produksi setinggitingginya (production centered development).
} 
telah mengganggu keseimbangan ekosistem dan mengundang perhatian dari berbagai pihak baik pemerintah, LSM, maupun lembaga donor asing untuk melakukan rehabilitasi dengan mengambil langkahlangkah pendekatan kepada masyarakat.

Tulisan ini bertujuan untuk mengidentifikasi dan menganalisa dinamika yang terjadi pada komunitas petani kentang di Dataran Tinggi Dieng dilihat dari tiga hal yaitu: 1) Transformasi sistem produksi pertanian; 2) Perubahan sosial komunitas petani kentang; dan 3) Intervensi pemberdayaan atas isu yang terjadi di Dataran Tinggi Dieng terkait dengan transformasi sistem produksi dan perubahan sosial komunitas petani kentang.

\section{Latar Belakang}

Sektor pertanian di Indonesia secara historis memiliki kontribusi bagi pertumbuhan ekonomi melalui peningkatan lapangan kerja, peningkatan produktivitas sebagian besar jenis tanaman, dan pengurangan kemiskinan. Namun kenyataannya saat ini kondisi pertanian indonesia berada di titik rawan, data Badan Pusat Statistik menunjukkan bahwa terjadi penurunan jumlah tenaga kerja sektor pertanian dari kurun waktu 2015-2017 sebesar 37,74 juta jiwa menjadi 35,92 juta jiwa. Data tersebut menunjukkan bahwa dalam kurun watu dua tahun tenaga kerja sektor pertanian berkurang sebanyak 1,82 juta jiwa. Implikasinya kemudian adalah terjadi perubahan strategi nafkah yang sebelumnya di sektor pertanian kemudian beralih ke sektor non pertanian. Tidak dipungkiri bahwa kondisi tersebut terjadi karena beberapa sebab seperti semakin rendahnya minat menjadi petani, banyaknya alih fungsi lahan pertanian, kepemilikan lahan oleh petani semakin menyempit, dan kebijakan pro impor terhadap produk-produk pertanian.

Selain persoalan yang telah disebutkan sebelumnya, lapangan kerja bidang pertanian saat ini dihadapkan dengan kondisi iklim yang tidak 
menentu ${ }^{2}$. Kondisi tersebut menyebabkan petani mengalami kesulitan untuk menentukan musim tanam dan pada kondisi tertentu menyebabkan mereka gagal panen. Hal ini dirasakan oleh petani kentang di Dataran Tinggi Dieng, Jawa Tengah, misalnya akibat air hujan yang terus menggerus lahan pertanian hingga longsor dan sulit untuk ditanami. Sekitar 7.758 hektar dari total sekitar 10.000 hektar di Dieng kritis, meliputi 4.000 hektar di Wonosobo dan sisanya di Banjarnegara. Data Pemerintah Kabupaten Wonosobo menyebutkan, erosi tanah di Dieng mencapai 4,5 juta ton per tahun ${ }^{3}$. Pergantian musim yang tidak menentu juga menyebabkan hama menjadi semakin resisten dan akhirnya biaya pupuk dan pestisida menjadi semakin tinggi, setelah memang sebelumnya petani sudah tergantung dengan sistem pertanian yang sifatnya high external input of agriculture (HEIA).

Sebelumnya, ketika komoditi kentang belum masuk ke kawasan Dataran Tinggi Dieng, petani mengusahakan tanaman tembakau dan palawija di lahan pertaniannya. Seiring dengan kenyataan bahwa kentang memiliki nilai ekonomis lebih tinggi dibanding dengan tembakau dan palawija, kemudian petani beralih mengusahakan tanaman kentang. Orientasi aktifitas pertanian sepenuhnya adalah untuk mengejar keuntungan materi dan peningkatan produktifitas. Dengan berubahnya komoditi pertanian, terjadi juga perubahan sistem pertanian yang sekaligus mempengaruhi proses-proses sosial yang berlangsung di komunitas petani kentang di Dataran Tinggi Dieng.

\section{Kajian Literatur dan Teori}

Perubahan sosial merupakan proses yang terus berkesinambungan, perubahan pada aspek tertentu mampu mempengaruhi entitas sosial secara komprehensif. Transformasi sistem produksi pertanian dari subsisten ke komersial memiliki dampak bagi sistem sosial, ekonomi, maupun ekologi di Dataran Tinggi Dieng. Kecenderungan menjadikan

\footnotetext{
2 Pertanian merupakan salah satu sektor yang paling rawan terkena dampak negatif perubahan iklim (Stern, 2006 dalam Susilowati, et al, 2010), yaitu meningkatnya resiko turunnya produksi dan produktivitas usaha tani.

${ }^{3}$ http://regional.kompas.com/read/2013/05/06/03185215/Galakkan.Kentang.Organik (diunduh 16 juni 2013 pukl 16:04)
} 
kentang sebagai tanaman primadona memberikan implikasi bahwa secara ekonomi kentang memberikan keuntungan dari penghasilan usahatani yang diperoleh. Namun demikian, permasalahan kemudian muncul dari aspek sosial dan ekologi. Kekayaan lebih dinikmati oleh pemilik tanah luas yang kemudian juga semakin merambah kawasan lindung. Kawasan Dataran Tinggi Dieng sebagai sumberdaya fisik pendukung mata pencaharian menjadi terganggu keseimbangannya. Persoalan tersebut mengundang perhatian dari berbagai pihak untuk turut andil dalam menyelesaikan persoalan sosial dan lingkungan di kawasan itu. Penulis menganalisa dengan menggunakan perspektif perubahan sosial dan yang meliputi identitas yang berubah, arah dan laju perubahan, aras analisis, dan sumber yang mendorong perubahan ${ }^{4}$; mengidentifikasi mekanisme yang mendasari terjadinya perubahan sosial5; serta menganalisa proses sosial yang terjadi atas intervensi pemberdayaan petani di Dataran Tinggi Dieng6.

\section{Metodologi}

Tulisan ini merupakan hasil studi literatur atas beberapa hasil penelitian serta penelusuran data reportase/berita tentang pertanian kentang di Dataran Tinggi Dieng. Analisa pada makalah tulisan ini merujuk pada tiga literatur utama yaitu Lauer (2001) mengenai perpsektif perubahan sosial, mengidentifikasi mekanisme yang mendasari terjadinya perubahan sosial, serta proses pemberdayaan. Literatur lainnya yang berkaitan juga digunakan sebagai pendukung untuk

\footnotetext{
${ }^{4}$ Lauer (2001)

${ }^{5}$ Harper (1989) menjelaskan dalam bukunya Exploring Social Change (Chapter 4-5) bahwa terdapat dua mekanisme perubahan sosial yaitu perspektif materialistik dan idealistik. Perspektif materialistik menekankan bahwa perubahan sosial bisa disebabkan oleh faktor material baik berupa faktor-faktor ekonomi atau pun teknologi yang berhubungan dengan produktifitas ekonomi. Teknologi baru maupun moda produksi ekonomi mendorong perubahan pada aspek interaksi, organisasi sosial, kultur, kepercayaan, dan norma-norma (perspektif Marxian). Perspektif idealistik dilihat sebagai ide, nilainilai, dan ideologi yang menyebabkan perubahan (perspektif Weberian). Ide terdiri atas pengetahuan dan kepercayaan-kepercayaan, nilai merupakan asumsi mengenai apa yang diinginkan dan tidak diinginkan, dan ideologi dipahami sebagai kombinasi antara kepercayaan dan nilai untuk memberikan legitimasi maupun justifikasi terhadap perilaku manusia (misalnya demokrasi, kapitalisme, sosialisme). ${ }^{6}$ Tiga dimensi utama dalam pemberdayaan yaitu pengetahuan, tindakan, dan kesadaran. Pengetahuan merupakan sumber yang mempengaruhi pengambilan keputusan, tindakan melihat pada siapa yang terlibat dalam proses reproduksi pengatahuan, dan kesadaran merupakan suatu proses dimana pengetahuan bisa mengubah pandangan yang selama ini telah diterima secara umum.
} 
melengkapi substansi tuliasan ini. Berdasarkan latar belakang, tulisan ini bertujuan untuk mengidentifikasi dan menganalisa 1) Transformasi sistem produksi pertanian; 2) Perubahan sosial komunitas petani kentang; dan 3) Intervensi pemberdayaan atas isu yang terjadi di Dataran Tinggi Dieng terkait dengan transformasi sistem produksi dan perubahan sosial komunitas petani kentang.

Adapun kerangka analisis dalam tulisan ini dijelaskan dalam

\section{Gambar 1.}

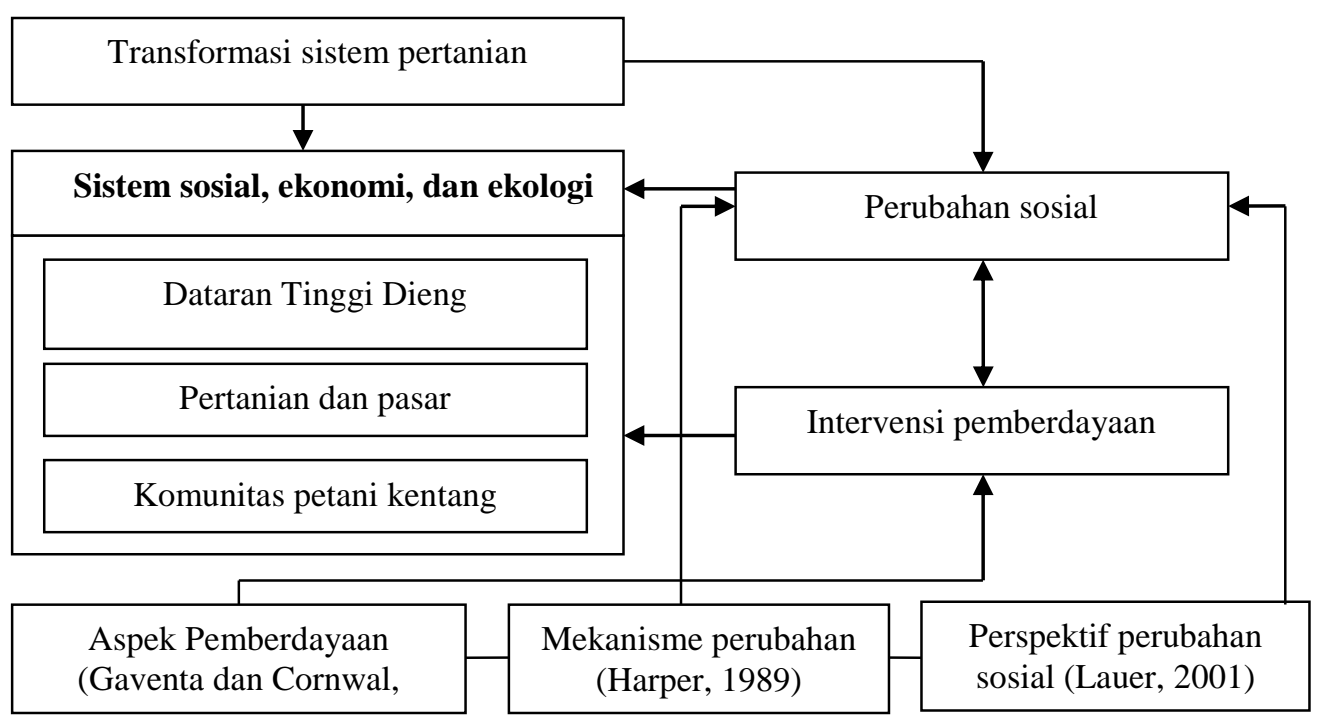

Gambar 1. Kerangka analisis

\section{B. Pembahasan}

\section{Transformasi Sistem Produksi Pertanian di Dataran Tinggi Dieng}

Dataran Tinggi Dieng merupakan kawasan yang berada di dua wilayah yaitu Kabupaten Banjarnegara dan Kabupaten Wonosobo dengan ketinggian 2.093 meter di atas permukaan laut (dpl). Iklim yang sejuk menyebabkan kawasan ini cocok sebagai tempat budidaya komoditas hortikultura, terutama kentang (Solanum Tuberosum L.) yang banyak dibudidayakan oleh petani setempat. Usaha tani kentang merupakan usaha pokok mayoritas petani di Dataran Tinggi Dieng dengan pola tanam kentang (musim 1)-kentang (musim 2)-kentang (musim 3) dalam satu tahun musim tanam. Budidaya kentang di Dataran Tinggi Dieng diperkenalkan sejak tahun 1970 dan memberikan hasil yang 
sangat menguntungkan ${ }^{7}$. Berdasarkan, pada dekade 80-an, tepatnya sekitar tahun 1983, masyarakat Dataran Tinggi Dieng mulai beralih dari tanaman tembakau ke tanaman sayur-sayuran. Tahun 1985, kentang masuk secara intensif dan diperkenalkan oleh petani dari Pangalengan, Jawa Barat ${ }^{8}$.

Sebelum kentang masuk menjadi komoditi yang bertahan ditanam hingga saat ini $^{9}$, jagung merupakan komiditi andalan bagi petani di Dataran Tinggi Dieng Ketika sistem tanam paksa (cultuur Stelsel) mulai diperkenalkan sekitar tahun 1830, Dataran Tinggi Dieng merupakan daerah yang memproduksi jagung dalam jumlah yang cukup tinggi selain Jawa Timur dan Madura. Pada periode tahun 1830-1900, di Dataran Tinggi Dieng lahan tegalan dapat menghasilkan dua atau tiga kali panenan jagung dalam waktu satu tahun, sebagian karena beberapa varietas memiliki masa tanam yang sangat pendek. Biasanya, panenan jagung ke dua hanya akan menghasilkan tiga perempat dari hasil panenan pertama. Jagung hampir menjadi tanaman monokultur, juga sering ditanam bersama tanaman lain atau tumpangsari bersama padi, kacang-kacangan, atau tembakau. Selama abad ke-19 proporsi lahan yang ditanami jagung dan palawija meningkat sedikit demi sedikit dari sekitar $20 \%$ menjadi $35 \%$ pada tahun 1880 . Kemudian pada akhir 1930 -an, lahan yang dibudidayakan oleh petani untuk tanaman pangan (musiman) adalah $45 \%$ untuk padi, $23 \%$ untuk jagung, dan $11 \%$ untuk ketela pohon.

Selain jagung dan palawija, antara tahun 1900-1940 Dataran Tinggi Dieng juga menjadi pusat penanaman tembakau. Tembakau merupakan jenis tanaman perdagangan yang ditana khusus untuk pasar lokal dan darah lain. Hasilnya per hektar dalam bentuk uang tunai yang sangat tinggi dan dapat digunakan oleh petani untuk menyewa tenag upahan dan membeli input lainnya seperti pupuk dan benih. Disebutkan bahwa, pupuk untuk tembakau juga dihasilkan dari kotoran manusia, juga pupuk kandang dari ternak dan kuda. Kondisi penanaman tembakau ini menunjukkan bahwa petani di Dataran Tinggi Dieng juga memelihara

\footnotetext{
${ }^{7}$ Wildan, 2004 dalam Bondansari et al, 2011

8 Turasih dan Adiwibowo (2012)

${ }^{9}$ Boomgard, 2002 dalam Li, Tania Muray, 2002, Transformasi Daerah Pedalaman di Indonesia, Bab 2. Jagung dan Tembakau di Dataran Tinggi di Indonesia 1600-1900, Jakarta: Yayasan Obor Indonesia.
} 
ternak. Persoalan kerugian mulai nampak dalam hal penanaman tembakau yang penyebabnya termasuk penggundulan hutan dan masalah yang berkaitan dengan kekurangan air. Konsumsi kayu bakar untuk mengeringkan daun tembakau di tempat yang tinggi mengurangi luas tutupan hutan. Meskipun di Dieng petani secara lokal telah menanam pohon seperti kemlandingan gunung (Albizzia montana) dan bahkan Eucalyptus yang diintroduksi dari luar dan disediakan oleh Dinas Kehutanan, namun kekurangan kayu bakar masih tetap terjadi. Daerah penanaman tembakau di Dataran Tinggi Dieng tidak dibuat dalam bentuk teras-teras, gambaran ini menunjukkan bahwa penanaman tembakau dilakukan di wilayah rawan dan menyebabkan ekspansi yang terus menerus.

Introduksi komoditi kentang di Dataran Tinggi Dieng memberikan wawasan baru bagi petani bahwa terdapat komoditi yang lebih menguntungkan dan berumur tanam pendek dibandingkan tembakau. Budidaya pertanian kentang memberikan nilai ekonomi yang tinggi bagi petani sehingga dilakukan dengan sangat intensif. Sebagian besar usahatani dilakukan pada lahan dengan kemiringan dia atas 30\% bahkan ada yang lebih dari 100\% dan kurang memperhatikan kaidah konservasi tanah dan air. Cara pengolahan yang demikian menyebabkan aliran permukaan (run off) yang tinggi dan menyebabkan longsor serta rusaknya lingkungan Daerah Aliran Sungai (DAS). Belum lagi ditambah dengan perilaku konsumtif terhadap penggunaan pupuk kimia dan pestisida, para petani dengan modal besar akan menggunakan pestisida yang berharga mahal dengan keyakinan bahwa semakin mahal harga pestisida maka bahan aktifnya akan semakin kuat untuk memberantas hama dan penyakit tanaman kentang, namun sayangnya banyak hama justru menjadi semakin resisten.

Masuknya pertanian kentang di Dataran tinggi Dieng semakin mengukuhkan praktek pertanian komersial oleh petani hingga saat ini. Beralihnya orientasi dari subsistensi pemenuhan kebutuhan menjadi komersial menyebabkan petani upaya intensifikasi dan ekstensifikasi untuk memaksimalkan keuntungan. Sejalan dengan apa yang pernah terjadi di Jawa pada masa pelaksanaan BIMAS, pertanian kentang ini 
juga memiliki pola yang sama. Pada satu sisi pertanian kentang ini mampu menaikkan harkat dan martabat petani secara ekonomi, tetapi di sisi lainnya juga menimbulkan kesenjangan sosial-ekonomi yang nyata. Petani kaya yang memiliki modal besar mampu menjadi juragan kentang dengan menanam komoditas tersebut pada lahan yang sangat luas, sedangkan petani kecil semakin teralienasi. Seperti mengulangi masa dimana tembakau menjadi tanaman utama, ekspansi lahan juga terjadi pada masa penanaman kentang. Luas areal tanam kentang di kawasan Dataran Tinggi Dieng dari tahun 1975 hingga tahun 1990 mengalami kenaikan yang sangat tinggi. Pada saat itu produktivitas kentang mencapai 20-25 ton per hektar ${ }^{10}$. Kawasan hutan di pegunungan pun berangsur habis dikonversi menjadi kebun kentang. Kementrian Lingkungan Hidup mencatat, dari luas Dataran Tinggi Dieng 619.846 ha, hutan yang tersisa tinggal 20,1 persen padahal idealnya 30 persen ${ }^{11}$.

\section{Perubahan Sosial Komunitas Petani Kentang di Dataran Tinggi Dieng}

Masuknya komoditi kentang telah menjadi titik pemaksimalan produksi usahatani baik melalui ekstensifikasi maupun intensifikasi. Introduksi komoditi komersial merupakan bentuk modernisasi bidang pertanian yang tidak dipungkiri memberikan pola baru dalam kehidupan komunitas petani. Hal yang paling mudah diamati di Dataran Tinggi Dieng adalah perubahan konsumsi pupuk yang awalnya berasal dari kompos, kotoran ternak, maupun kotoran manusia menjadi pupuk dan pestisida kimia. Modernisasi bidang pertanian tersebut memberikan cara pandang baru untuk bisa memaksimalkan produksi dan mengejar keuntungan ekonomi. Modernisasi pertanian melahirkan mode baru perekrutan buruh di luar rumah tangga, bahwa pada era tembakau di Dataran Tinggi Dieng model perekrutan buruh tersebut sudah dimulai, demikian berlanjut menjadi lebih banyak setelah kentang masuk menjadi komoditi utama ${ }^{12}$.

Desakan ekonomi dan pertumbuhan penduduk menyebaban lahanlahan di Dataran Tinggi Dieng semakin berkurang. Akibatnya

\footnotetext{
${ }^{10}$ Bondansari et al, 2011

${ }^{11}$ Kompas, 03 Juni 2011

${ }^{12}$ Long (1987), Boomgard (2002), Turasih dan Adiwibowo (2012); Bondansari et al (2011)
} 
perambahan bagi peruntukkan lahan usaha tani menjadi massif. Ketika populasi penduduk masih kecil, pertanian bertujuan untuk kepentingan subsistensi rumahtangga. Petani mempraktekkan sistem bera dan menanaminya dengan jagung serta palawija, sewaktu-waktu mereka bisa berpindah ke lokasi tanah yang lain dengan leluasa. Pada saat itu pengalaman dan tenaga petani masih terbatas untuk mengolah lahan yang sangat luas. Faktor tersebut menjadikan mereka membiarkan lahanlahan kosong. Kemudian masuknya revolusi hijau pada dekade 1960-an, meskipun tidak berpengaruh secara langsung tetapi memberikan dampak yang signifikan. Salah satu prioritas pemerintah Orde Baru pada saat itu adalah memperluas jalan-jalan baru termasuk di daerah dataran tinggi yang terpencil. Pada tahun 1978 di kawasan Dataran Tinggi Dieng area jalan aspal meningkat dari 27 kilometer menjadi 62 kilometer, dan jumlah desa yang mampu mengakses jalan (aspal dan berbatu) meningkat dari kira-kira 10 persen menjadi 30 persen $^{13}$. Perbaikan jalan memungkinkan proses distribusi panen menjadi semakin mudah. Perbaikan jalan juga menekan biaya transportasi karena petani tidak perlu repot menjualnya ke kota sebab banyak pedagang pengumpul yang merupakan perpanjangan tangan pedagang dari Surabaya, Jakarta, dan Semarang akan membelinya langsung dari ladang.

Sistem penghidupan petani di Dataran Tinggi Dieng yang sudah tergantung dengan pertanian kentang tersebut tidak terlepas dari penetrasi pengetahuan luar yang membawa kentang hingga sampai ke wilayah tersebut. Dalam pemahaman sosiologi nafkah mazhab Bogor yang dikembangkan oleh Sajogyo ${ }^{14}$, perkembangan sistem penghidupan dan nafkah pedesaan tidak bisa dilepaskan dari keseluruhan proses destabilisasi sistem sosial-ekonomi yang melanda pedesaan. Prosesproses adaptasi ekonomi dan ekologis yang dibentuk oleh petani di Dataran Tinggi Dieng baik secara individu maupun komunitas merupakan upaya untuk menyelaraskan eksistensi mereka terhadap perubahan sosial.

\footnotetext{
13 Arbangiyah (2012)

${ }^{14}$ Dharmawan (2013)
} 
Pada tahap selanjutnya eksistensi petani terhadap dinamika pembangunan di Dataran Tinggi Dieng tersebut menciptakan polarisasi yang mencolok antara petani kaya dan petani miskin. Sistem penghidupan dan nafkah dari pertanian kentang ini memberi konsekuensi pada semakin tajamnya potret kemiskinan di Dataran tinggi Dieng. Pembangunan pertanian ala modernisasi yang mengedepankan modal besar pada titik tertentu menghancurkan tatanan sosial serta menciptakan keserakahan untuk menguasai sebanyak mungkin modal lahan termasuk dengan merambah hutan sebagai area tangkapan. Eksploitasi terhadap daerah miring dan area hutan tersebut menghasilkan kehancuran pada aspek sosial, ekonomi, dan ekologi secara sistemik. Modernisasi pertanian di Indonesia $^{15}$ menunjukkan pembentukan struktur kelas kapitalis dimana terdapat petani kaya yang menguasai modal (tanah), dominasi terhadap akses teknologi dan kredit, serta kontrol bagi keberadaan usaha tani yang lebih leluasa dibanding petani kecil.

Perubahan yang kentara terlihat berikutnya adalah dari kentang pula muncul orang-orang kaya yang lazim disebut "haji kentang", mereka bisa naik haji dan membangun masjid dari penghasilan usahatani kentang ${ }^{16}$. Pertanian modern semakin memunculkan rasionalitas di kalangan petani. Pada masa lalu, pertanian di Dataran Tinggi Dieng selalu diawali dengan ritual sebelum menanam. Ritual kebudayaan yang terkait dengan pertanian seperti nglekasi, wiwit, ruwat bumi, dan baridan yang tujuan utamanya untuk meminta berkah kepada leluhur supaya pada musim tanam diberikan kelancaran. Ritual tersebut dipengaruhi budaya Hindu yang pada saat itu masih kental di Dataran Tinggi Dieng. Pada perkembangannya saat kentang masuk ke Dataran Tinggi Dieng, nilai-nilai tersebut digantikan oleh rasionalitas bahwa orientasi pertanian kentang adalah keuntungan ekonomi. Sebagai komoditi yang bernilai tinggi, kentang mempengaruhi kebudayaan dan cara hidup baik individu maupun masyarakat.

\footnotetext{
${ }^{15}$ Merujuk Wright (1978) dalam Sanderson (2010)
}

16 Turasih dan Adiwibowo (2012) 
Mengacu perspektif perubahan sosial ${ }^{17}$ meliputi identitas yang berubah, arah dan laju perubahan, aras analisis, dan sumber yang mendorong perubahan, dapat dianalisa bahwa terjadi perubahan sosial di Dataran Tinggi Dieng terkait dengan masuknya komoditi kentang sebagai sumber mata pencaharian utama petani. Aspek-aspek perubahan tersebut selengkapnya disajikan pada Tabel 1.

Tabel 1. Analisis perubahan sosial komunitas petani kentang di Dataran Tinggi Dieng

\begin{tabular}{|c|c|c|}
\hline No & Komponen Perubahan & Dimensi Perubahan \\
\hline 1 & Identitas yang berubah & $\begin{array}{l}\text { Sistem sosial, ekonomi dan ekologi. Pola } \\
\text { pertanian subsisten ke arah komersial dan } \\
\text { perubahan tata nilai tradisional menjadi } \\
\text { modern. }\end{array}$ \\
\hline 2 & Arah dan Laju Perubahan & $\begin{array}{l}\text { Siklikal, dalam waktu yang relatif singkat, } \\
\text { dan mengalami kemunduran }\end{array}$ \\
\hline 3 & Sumber perubahan & $\begin{array}{l}\text { Eksogen berupa introduksi tanaman } \\
\text { kentang dari pihak luar (Jawa Barat) } \\
\text { sekaligus pengenalan teknologi pertanian } \\
\text { modern }\end{array}$ \\
\hline 4 & Aras & $\begin{array}{l}\text { Komunitas petani kentang (mikro); } \\
\text { Kawasan Dataran Tinggi Dieng (Meso) }\end{array}$ \\
\hline 5 & Perspektif & Materialistik \\
\hline
\end{tabular}

Keterangan: merujuk dari berbagai sumber

Perubahan sosial bisa disebabkan oleh faktor material baik berupa faktor-faktor ekonomi atau pun teknologi yang berhubungan dengan produktifitas ekonomi. Teknologi baru maupun moda produksi ekonomi mendorong perubahan pada aspek interaksi, organisasi sosial, kultur, kepercayaan, dan norma-norma. Karl Marx ${ }^{18}$ sebagaimana dijelaskan oleh menganggap bahwa moda produksi (force of production) merupakan pembentuk sistem sosial dan penyebab perubahan sosial. Relasi produksi membentuk struktur masyarakat yang ditentukan oleh penguasaan moda produksi. Hal ini seperti yang terjadi di Dataran Tinggi Dieng dimana masuknya komoditi kentang telah mengubah beberapa aspek baik sistem sosial, ekonomi, maupun ekologi secara keseluruhan. Moda produksi

\footnotetext{
${ }^{17}$ Berdasarkan Lauer (2001) Perspektif perubahan sosial meliputi identitas yang berubah, arah dan laju perubahan, aras analisis, dan sumber yang mendorong perubahan.

${ }^{18}$ Harper (1989)
} 
yang kemudian sangat berpengaruh sebagai pendorong perubahan sosial adalah tanah, benih kentang, dan tenaga kerja.

Perubahan-perubahan yang terjadi di Dataran Tinggi Dieng menyebabkan stratifikasi sosial ${ }^{19}$ dengan merujuk pada teori kelangkaan. Teori kelangkaan beranggapan bahwa penyebab utama timbul dan semakin intensnya stratifikasi disebabkan oleh tekanan jumlah penduduk. Makin meningkatnya tekanan penduduk menyebabkan masyarakat hortikultura makin memperhatikan kepemilikan tanah. Semakin langka tanah yang layak untuk bercocok tanam, menyebabkan 'egoisme' dalam kepemilikan tanah dan orang mulai mempunyai tanah yang lebih luas dibanding yang lain. Egoisme pemilikan tanah dalam pemikiran Marxisme menyebabkan terhapusnya kepemilikan bersama. Dengan meningkatnya tekanan penduduk dan teknologi, perbedaan akses terhadap sumberdaya makin nyata, dan stratifikasi semakin intensif dengan dorongan politik yang semakin besar. Hal seperti ini terjadi pada komunitas petani kentang di Dataran Tinggi Dieng (selengkapnya lihat Gambar 2).

Gambar 2. Proses munculnya stratifikasi sosial di Dataran Tinggi Dieng

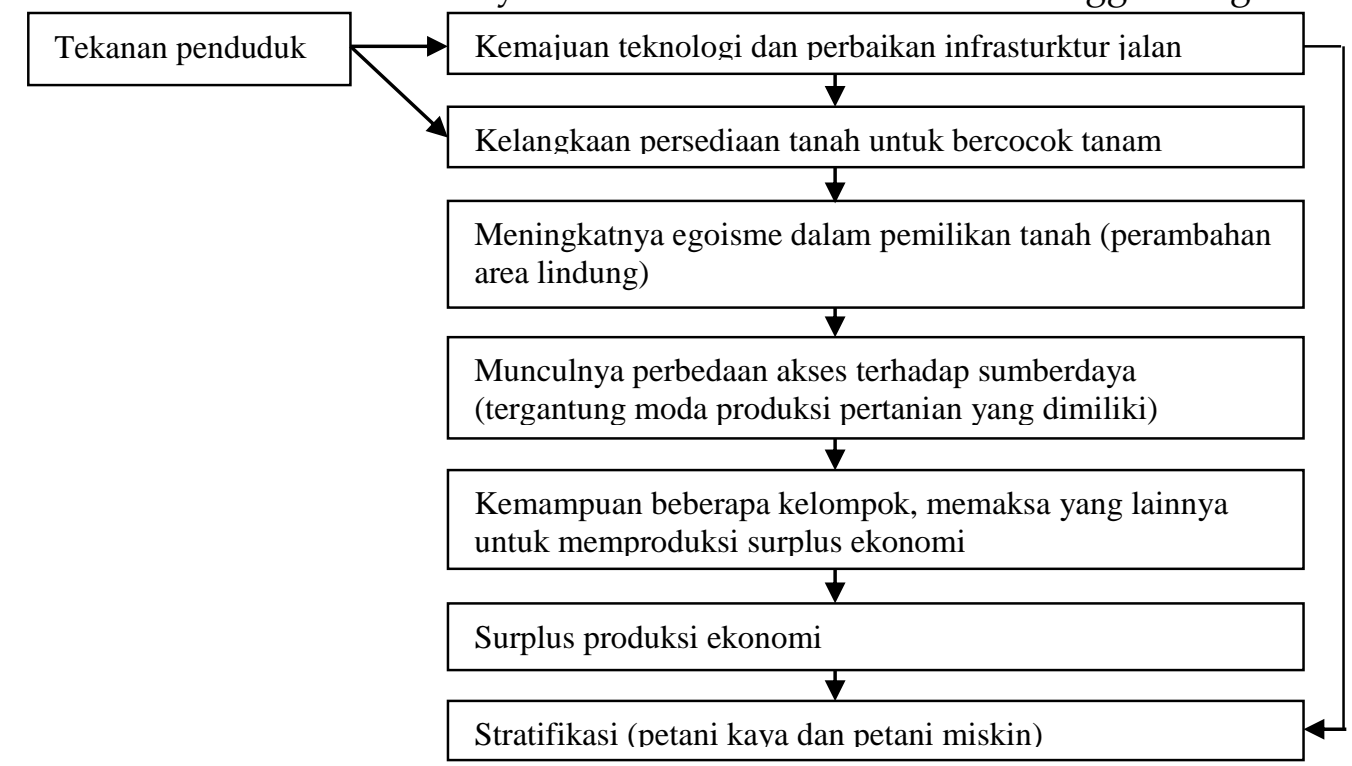

Keterangan: Dimodifikasi dari diagram teori kelangkaan stratifikasi sosial (Sandoerson, 2010) hal. 160

\footnotetext{
${ }^{19}$ sebagaimana dijelaskan oleh Sanderson (2010) dengan mengutip pemikiran Harner (1970), Morton Fried (1967) dan Rae Lesser Blumberg (1978) mengenai teori kelangkaan
} 


\section{Intervensi Pemberdayaan Berdasarkan Isu Di Dataran Tinggi Dieng}

Fenomena yang terjadi di Dataran Tinggi Dieng pasca masuknya komoditi kentag sebagai unggulan dan sumber matapencaharian petani memberikan dampak tidak hanya bagi komunitas petani di wilayah tersebut, namun merambah ke area di bawahnya. Mengingat Dieng merupakan hulu dari DAS Serayu yang memberikan suplai energi bagi pembangkit listrik tenaga air (PLTA) wilayah Jawa dan Bali. Perhatian bagi isu kerusakan lingkungan akibat pertanian kentang di Dataran Tinggi Dieng mendapatkan perhatian dari berbagai pihak mulai dari pemerintah, swasta, hingga LSM. Berbagai upaya penyelamatan lingkungan Dieng terkait dengan pola pertanian tanaman monokultur telah dicanangkan. Tahun 2005 dicanangkan pembentukan hutan sekolah di wilayah Wonosobo. Tahun 2006 dilakukan sosialisasi kepada penduduk dan petani Dieng yang selama ini memanfaatkan lahan untuk budidaya tanaman kentang. Selain itu, metode Pengelolaan Hutan Bersama Masyarakat (PHBM) juga dilaksanakan namun hasilnya masih belum sesuai dengan harapan ${ }^{20}$. Penyebabnya selama ini dibebankan kepada petani sebagai aktor yang berperan merusak lingkungan.

Pada tahun 2007 Pemerintah Kabupaten Wonosobo membentuk Tim Kerja Pemulihan Dieng (TKPD) sebagai sebuah bentuk kepedulian terhadap kerusakan lingkungan di Dataran Tinggi Dieng, kelembagaannya dikukuhkan melalui SK Bupati Wonosobo tahun $2007^{21}$. Bahkan Bupati Wonosobo memberikan larangan keras bagi petani untuk tidak menanam di lahan dengan kontur kemiringan yang sudah tidak bisa ditoleransi. Pada tahun 2012, Pemerintah Kabupaten Banjarnegara mendapatkan bantuan dari UNDP (United Nation Development Programme) melalui proyek proyek Penguatan Komunitas Berbasis Hutan dan Manajemen Aliran Sungai (SCBFWM). Berbagai program yang terus digalakkan tersebut meskipun mengusung perhatian bagi aspek sosial,

20 Turasih, et al, (2010)

${ }^{21}$ www.savedieng.org 
ekonomi, dan lingkungan pada kenyataan masih bersifat mekanistis dan lebih menekankan lingungan sebagai objek utama. Padahal permasalahan di Dataran Tinggi Dieng bukan semata-mata hancurnya lingkungan akibat usahatani kentang yang terlalu menekankan produktivitas, tetapi juga munculnya stratifikasi sosial akibat konsentrasi penguasaan lahan.

Permasalahan sosial hasil dari stratifikasi sosial terkait konsentrasi penguasaan lahan belum menjadi fokus perhatian pelaku pemberdayaan bagi pemulihan Dieng dan hasilnya adalah petani selalu menjadi tersangka. Sebagai contoh di Desa Kareng Tengah ${ }^{22}$ Dataran Tinggi Dieng adalah 77,42 persen petani pemilik dimana 31,23 persen merupakan pemilik dengan luas dibawah 0,3 ha, 35,48 persen petani dengan kepemilikan lahan 0,5-1 ha dan hanya 9,68 persen merupakan pemilik lahan 1-2 ha. Petani pemilik tersebut murni melakukan usahatani di atas lahan yang dimilikinya. Selain status milik, terdapat juga petani dengan status lahan sewa. Petani yang melakukan sewa tersebut adalah mereka yang tidak memiliki lahan sama sekali dimana jumlahnya 6,54 persen. Kategori penguasaan lahan lainnya adalah petani pemilik sekaligus penyewa lahan yang berjumlah 12,90 persen dari seluruh responden. Sejumlah 9,68 persen merupakan pemilik lahan 0,1 ha- 0,3 ha dan 3,22 persen merupakan pemilik lahan 0,3 ha-0,5 ha. Berdasarkan data tersebut diketahui bahwa petani yang tidak memiliki lahan tidak melakukan penyewaan dan menyebabkan mereka menjadi buruh tani. Persentase petani yang memiliki lahan dibawah 0,3 ha relatif mendominasi di Dataran Tinggi Dieng ditambah dengan buruh tani. Kenyataannya akumulasi lahan hanya bisa dilakukan oleh petani yang memiliki modal lebih (lihat kembali Gambar 2. Mengenai stratifikasi sosial akibat egoisme kepemilikan lahan).

Pendekatan pemberdayaan masyarakat yang diperuntukan untuk mengangkat daya mereka yang lemah seharusnya mengutamakan tiga

\footnotetext{
22 Berdasarkan data penelitian Turasih dan Adiwibowo (2012) mengenai kepemilikan lahan di Desa Karang Tengah
} 
dimensi yaitu pengetahuan, tindakan, dan kesadaran ${ }^{23}$. Pengetahuan merupakan sumber yang mempengaruhi pengambilan keputusan, tindakan melihat pada siapa yang terlibat dalam proses reproduksi pengetahuan, dan kesadaran merupakan suatu proses dimana pengetahuan bisa mengubah pandangan yang selama ini telah diterima secara umum. Namun demikian, hal yang seringkali tidak disadari perhatian bagi pemunculan kesadaran kritis masyarakat sering diabaikan karena pelaku pemberdayaan disibukkan dengan persoalan teknis.

Gambar 3. Dimensi hubungan kekuasaan dalam pemberdayaan (Gaventa dan Cornwall, 2002)

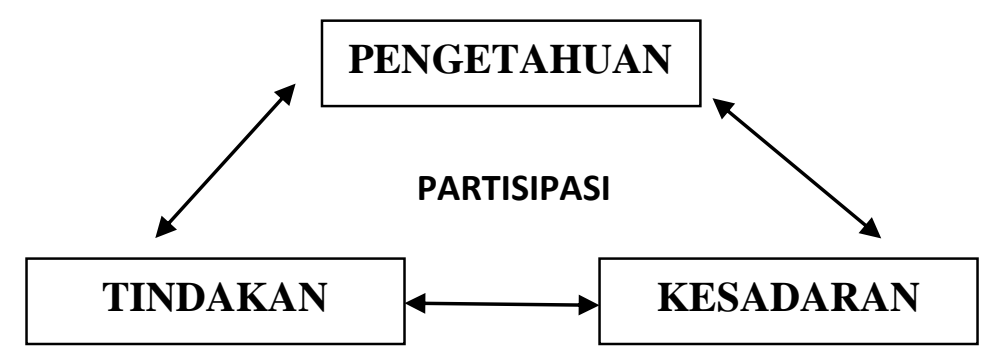

Kompleksitas isu yang terjadi di Dataran Tinggi Dieng menyebabkan tumpang tindih proses pemberdayaan. Munculnya kondisi berdaya yang diharapkan terjebak oleh mekanisme penilaian keberhasilan proses pemberdayaan yang sangat mekanistik. Programprogram pemulihan Dieng menciptakan sekat antara yang berdaya dengan yang lemah, subjek dan objek, bersifat top down dan masalah sosial seperti kemiskinan dan egoisme kepemilikan lahan dilihat dengan kacamata kuda. Akhirnya, aktifitas-aktifitas yang yang seharusnya memberdayakan justru tidak tepat guna dan tidak tepat sasaran sekaligus semakin mengukuhkan production centered development karena ukuran-ukuran pemulihan Dieng adalah luas tutupan lahan. Akhirnya proses-proses pemberdayaan juga hanya menciptakan kesadaran palsu (false consciousness) karena kelompok utama yang peru diperhatikan (kelmpok miskin) tidak merasakan manfaatnya dengan baik. Hal ini

${ }^{23}$ Gaventa dan Cornwall (2002) 
masih menjadi pekerjaan rumah bagi semua pihak yang memiliki kepentingan di wilayah tersebut.

Untuk melakukan pemulihan kawasan Dieng diperlukan langkah yang matang meliputi aspek sosial dan kondisi fisik lingkungan. Penggunaan lahan dengan kemiringan tinggi untuk pertanian kentang dan tembakau oleh petani disebabkan ketidaktahuan masyarakat tentang tata ruang lingkungan. Karena itu, dibutuhkan pendampingan secara intensif dari semua pihak agar SDM dan kesadaran lingkungan masyarakat meningkat, sehingga proses konservasi lahan tidak menganggu ekonomi masyarakat ${ }^{24}$. Pilihan menanam kentang saat ini sudah disadari oleh petani bukan satu-satunya penjamin kehidupan mereka, namun mereka belum menemukan pengganti tanaman yang memiliki keuntugan ekonomi setara dengan kentang dan juga mampu menjamin keberlanjutan lingkungan. Namun demikian, berbagai pihak termasuk Pemerintah Daerah sebagaimana disampaikan oleh Hadi Supeno ${ }^{25}$, wakil bupati Banjarnegara bahwa alternatif komoditi lain belum ditemukan.

\section{Kesimpulan}

Komoditi kentang yang hadir setelah era jagung dan tembakau di Dataran Tinggi Dieng pada tahap awal memberikan kontribusi ekonomi yang signifikan bagi petani. Nilai jual yang tinggi dan musim tanam yang pendek menyebabkan petani secara intensif melakukan usahatani kentang. Masuknya komoditi kentang membuka pintu modernisasi pertanian dan menciptakan stratifikasi sosial yang mencolok pada komunitas petani kentang dalam hal kepemilikan moda produksi. Seiring dengan meningkatnya jumlah penduduk, usahatani ini kemudian bersifat destruktif bagi lingkungan karena perambahan area lindung yang diperuntukkan bagi lahan pertanian. Imbasnya adalah penurunan daya dukung lingkungan dan penurunan penghasilan petani. Isu yang terjadi

\footnotetext{
${ }^{24}$ Wawancara www.suaramerdeka.com kepada Dwi Yama Ketua TKPD, 22 Juli 2011

${ }^{25}$ Wawancara www.kompas.com kepada Hadi Supeno, Wakil Bupati Banjarnegara, 7 Juni 2013
} 
di Dataran Tinggi Dieng menarik perhatian berbagai pihak untuk melalukan pemulihan melalui proses pemberdayaan. Sayangnya, proses pemberdayaan yang dilakukan masih bias teknis dan boleh menyentuh golongan miskin serta selalu menjadikan petani sebagai objek.

Tulisan ini ditutup dengan kesimpulan bahwa jargon pembangunan ala modernisasi menciptakan disorientasi pembangunan yang seharusnya mampu memberdayakan tetapi justru mempertajam kutub kemiskinan di pedesaan. Pertanian modern yang masuk ke Dataran Tinggi Dieng menciptakan ketergantungan sistem sosial-ekomi lokal pada struktur kapitalis pasar yang menciptakan kerusakan ekologi. Transformasi sosial yang terjadi di Dataran Tinggi Dieng merupakan bentuk kooptasi atas otoritas negara (pemerintah) dan kapitalis (pasar) yang tanpa disadari masih menjadikan petani pedesaan sebagai objek pembangunan. 


\section{DAFTAR PUSTAKA}

Arbangiyah, Raudhotun. Perubahan Pola Pertanian Rakyat di Dataran Tinggi

Dieng (1985- 1995). [Skripsi] Jurusan Sejarah, Fakultas Ilmu Budaya UI. 2012.

Bondansari, et al. Studi Tentang Budidaya Tanaman Kentang (Solanum

Tuberosum L.) di Dataran Tinggi Dieng Kajian Dari Aspek Ekonomi dan Aspek Lingkungan. Jurnal Pembangunan Pedesaan Volume 11 Nomor 1. Juni 2011.

Dharmawan, Arya Hadi. Sistem Penghidupan Pedesaan: Menggali dan Mengenali Sosiologi Nafkah (Livelihodd Sociology) Mazhab Bogor Dimensi-Dimensi Sistem Penghidupan. [Artikel] MK. Gerakan

Sosial dan Dinamika Masyarakat Pedesaan. Program Studi Sosiologi Pedesaan Sekolah Pascasarjana IPB. 2013.

Harper, Charles L. Exploring Social Change (Chapter 4-5). New Jersey: Prantice Hall. 1989.

Li, Tania Muray. Transformasi Daerah Pedalaman di Indonesia, Jakarta:

Yayasan Obor Indonesia. 2002.

Long, Norman. Sosiologi Pembangunan Pedesaan, Jakarta: PT Bina Aksara.1987.

Sanderson, Stephen K. Sosiologi Makro: Sebuah Pendekatan Terhadap

Realitas Sosial, Edisi Kedua (cetakan ke-50 diterjemahkan oleh Farid Wajidi dan S. Menno, Jakarta: PT Raja Grafindo Persada. 2010.

Sajogyo, Modernization without Development, Reprint The Journal of Social Studies. January 1982. Dacca Bangladesh. 1982.

Susilowati, Sri Hery. et al. Indikator Pembangunan Pertanian dan Pedesaan:

Karakteristik Sosial Ekonomi Petani Padi, Proposal RPTP TA. 2010. Pusat Analisis Ekonomi dan Kebijakan Pertanian, Badan Penelitian dan Pengembangan Pertanian. Departemen Pertanian. 2010.

Turasih, et al. Laporan Akhir PKMM Pengembangan Metode Partisipatif 
298 | Turasih - Transformasi Sosial Komunitas Petani...

Berbasis Masyarakat Dalam Rangka Implementasi Agroforestri di Dataran Tinggi Dieng Melalui LEISA (Low External Input for Sustainable Agriculture). Institut Pertanian Bogor. 2010.

Turasih, dan Adiwibowo, Soeryo. Sistem Nafkah Rumah Tangga Petani

Kentang di Dataran Tinggi Dieng (Kasus Desa Karangtengah,

Kecamatan Batur. Kabupaten Banjarnegara, Jawa Tengah). Sodality: Jurnal Sosiologi Pedesaan. September 2012.

[Koran] Bencana Dieng Dilema Utang Para Juragan Kentang. 201103 Juni. Kompas. Regional: 1 \&15 (Kol.1-5).

[Website] Galakkan Kentang Organik. 2013. wwww.kompas.com. http://regional.kompas.com/read/2013/05/06/03185215/Galakkan.Kentan g.Organ ik (diunduh 16 juni 2013 pukl 16:04)

[Website] About Us Tim Kerja Pemulihan Dieng (TKPD). www.savedieng.org. http://www.savedieng.org/index.php?view=article\&catid=35\%3Aprofil \&id $=49 \% 3 \mathrm{Aa} \quad$ bout-us\&format $=$ pdf\&option $=$ com content\&Itemid $=63$ (diunduh 13 Juni 2013, pukul 21.02 WIB)

[Website] Pemulihan Kawasan Dieng, Masyarakat Jangan Selalu Disalahkan. www.suaramerdeka.com.http://www.suaramerdeka.com/v1/index.php/rea d/news/2011/07/22/91617/Pemulihan-Kawasan-Dieng-Masyarakat-JanganSelalu-Disalahkan (diunduh 13 Juni 2013 pukul 21.00 WIB)

[Website] Buah Simalakama Dieng Bernama Kentang. www.kompas.com.http://regional.kompas.com/read/2013/06/07/1958179 8/Buah.Sima kalama.Dieng.Bernama.Kentang (diunduh 12 Juni 2013 pukul 16:02) 